\title{
LIFESTYLE ACCORDING TO AYURVEDA IN COVID-19 PANDEMIC
}

\author{
Dr. Krutika vijaykumar kamble 1 ${ }^{凶}$, Dr. Suvarna Dhawale 2 \\ ${ }^{1}$ Final year MD (Rachana sharir) BSDT's Ayurveda Mahavidyala, Wagholi, Pune, Maharashtra, \\ India \\ ${ }^{2}$ MD (Rachana sharir) Guide \& HOD, Department of Rachana sharir, BSDT 's Ayurveda \\ Mahavidyalaya, wagholi, Pune, Maharashtra, India
}

DOI: https://doi.org/10.29121/granthaalayah.v8.i9.2020.1445

Article Type: Research Article

Article Citation: Dr. Krutika vijaykumar kamble, and Dr. Suvarna Dhawale. (2020). LIFESTYLE ACCORDING TO AYURVEDA IN COVID-19 PANDEMIC. International Journal of Research -

GRANTHAALAYAH, 8(9), 136-140

https://doi.org/10.29121/granthaa

layah.v8.i9.2020.1445

Received Date: 07 September 2020

Accepted Date: 29 September 2020

Keywords:

Dinacharya

Aharavidhivisheshayatan

\section{ABSTRACT}

Background: The current covid-19 Pandemic situation has affected many lives, their health and well-being. This pandemic situation undoubtedly contribute to sudden change in daily routine like social distancing, isolation leads to emotional distress and increased risk for psychiatric illness. Day by day increase in number of patients of covid-19 put all of us in great fear, stress, uncertainty about life, loss of will power, loss of positivity about life. Ayurveda does not only deal with physical wellness but mental wellness also. Ayurveda, the science of life dealing with maintenance of everyones health and eliminating rogas From body. Ayurveda will definitely help us out from this worst situation by some easy lifestyle hacks. Ayurveda has already gifted us with lots of easy going daily routine Concepts for betterment of life. Now it is the time to when we should understand importance of Ayurveda and pick some lifestyle hacks according to Ayurveda such as Dincharya, Ratricharya, Ritucharya, Ahara, Rasayana, Yoga, pranayama etc.

Objectives: An overview of Dinacharya and Ahara in covid-19 pandemic situation for physical and mental health improvement.

\section{INTRODUCTION}

"Ayurveda" is the system designed to distinctly explained the merits and demerits, state of happiness or otherwise good and bad for life and the life itself within their parameters. [1] The purpose of Ayurveda is to procure a good health to accomplish constituted duty, acquisition of wealth, contentment of desires and salvation. So, these four factors constitute the objective of the 'Purusha'. [2]

Sushrutacharya describes the features of a healthy man, Doshas (Vata, Pitta, Kapha), Agni (digestive fire), Dhatus, Malas (waste products) and Kriyas are normal, Atma (soul), Indriya (sense organ) and Manas (mind) are peaceful is said to be healthy. One should regularly follow healthy lifestyle, diet and regimen, which keep good health and prevent diseases, which are not manifested [3]

According to word heath organization Health is clearly defined as a state of complete physical, mental and social well-being and not merely abscene of disease or infirmity." [4]

The current guidelines of AYUSH Ministry, Government recommend personal hygiene guidelines for preventive measures and boosting immunity. These guidelines recommend Ayurvedic tea and Decoction (kadha). Ingredients are Tulsi, Dalchini, kalimirch, shunthi, (Dry ginger), and Manuka (Raisin) jaggery or fresh lemon for better taste as immunity promoting measures against COVID-19. Cold, frozen, heavy junk food and other Rajasic and Tamsik food

(C) 2020 The Author(s). This is an open access article distributed under the terms of the Creative Commons Attribution License, which permits unrestricted use, distribution, and reproduction in any medium, provided the original author and source are credited. 
should avoid for healthy lifestyle. Recommendations such as to take appropriate rest, timely sleep, exposure to sunlight, and practice of Yogasana and Pranayama also help to balance our body, mind, and lifestyle. [5]

\subsection{IMPORTANCE OF DINACHARYA AND AHARA}

The concept of Dinacharya is so important and useful in today's Era that our Ancient Acharya also wrote all principles in Brihatrayi about Dinacharya. All life style disorders can be prevented by adopting Dinacharya. It also helps to establish balance in one's constitution. It also regularises a person's biological clock.

Ahara is considered as Mahabhaishajya (the superior medicine).[6] The healthy body as well as the disease are nothing but the outcome of Ahara and daily routine (Dinacharya). In Ayurveda, Ahara and method of cooking, method of eating has equal Importance. The one who consumed food according to given principles will always blesses with satisfaction of life. Oja, Teja, bala,,Dhatus and senses that is Health is totally depend Upon Food. [7] Ahara is main fuel for Agni (fire inside the body) that body is sustained upon. According to Charak Samhita All living things are totally depend upon food. Good voice complexion long and healthy life happiness, satisfaction, growth, strength, and intelligence are all outcomes of food. [8] In present era we don't care of Nutritional value of food and only take cares of our taste buds which is harmful for our life.. Ahara is the most Important factor for sustenance of life. It is described as foremost pillar among the three pillars of life that is Ahara, Nidra and Bramhacharya. When body is supported by the Trayopstambha.[9] It is endowed by growth, strength and complexion.

\subsection{OBJECTIVES}

1) Overview of dinacharya according to Ayurveda in covid pandemic situation.

2) Importance of ahara in covid pandemic situation.

3) Physical and mental health improvement by Ayurveda.

\section{MATERIAL AND METHOD}

\subsection{STUDY DESIGN - OBSERVATIONAL STUDY}

The present work is primarily based on theoretical research. The material were collected from the classical Ayurvedic literatures, magazine and research journals.

- Dinacharya

Rulls which should followed by the one who always desires for Good health and betterment of life are included in Dinacharya. [10]

\section{1) Brahmmuhurte Jagrana [11]}

One should always Wake up Early in the morning always gifted with health. Morning's calm, quite and positive vibes helps in meditation, Study, yoga, feeling of happiness and freshness in Brahmmuhur It is considered as the apt time for waking up. It is approximately two muhurtas i.e. 96 minutes before sunrise in that region.

\section{2) Usha jalapaan [12]}

Drinking water in brahmuhurt called ushajalapaan.

Luckwarm water is indicated in this pandemic situation, as this stimulates hunger and improve digestive fire, helps digestion, help in throat pain, hepls in hiccups reduction and regulates Dushta vata and Kapha

\section{3) Malotsarga Vidhi [13]}

Complete concentration with silence helps in complete evacuation of mala (stool and urine)

Evacuation of Malas should be done when veg (urge) is felt. These Vegas should not be suppressed, will cause shira shoola (Head ache), Apanvayu urdhva gati, pain (cutting type). That means the one should not supress Adharniya veg otherwise it will cause different type of pain and discomfort. Also, evacuation should not be done forcefully otherwise it will cause Arsha (piles), Fissure, Rectal prolapse etc. 


\section{4) DantDhawan, Jivha Nirrlekhana and Achamana [14], [15]}

Dantadhavan should be done with katu,Tikta,kashay Ras, as they are helpful to prevent Kahaj oral diseases. After brushing powdered kushta, Trikatu, Triphala and Trijataka with honey should be applied to tooth and gum. Madhur rasa hepls to prevent vataja and pittaj disease. Acharya shushruta mention Madhur rasa. Tongue cleaning should be done after brushing it prevents Mukha Daurgandha (halitosis), vairasya (faulty taste) and Aruchi (tastelessness) Amalaki kwath (decoction) is used for face and eyes cleaning after brushing.

Main entery for many disease is mouth passage. It should be cleaned and germfree for goodhealth.

\section{5) Anjana [16], [17]}

Two types of Anjana are below -

1) Souvira Anjana

2) Rasa Anjna

Souviraanjana has advised for daily use.it helps in maintaining healthy eye and vision. It prevents Daha (burning), kandu (itching), Mala (eye debris), vedana (pain), klinnata (watery eye) etc.

Rasanjana has advised for every $5^{\text {th }}$ or $8^{\text {th }}$ day at night to evacuate excessive kapha dosha. Teja in eye should be protected from excessive kapha or kleda.

\section{6) Nasya}

There are 5 types of Nasya

1. Navana, 2. Avpeedan, 3. Dhyapana, 4. Dhoom, 5. Pratimarsha [18]

Pratimarsha nasya has advised for daily use, Anu taila is usually used for this nasya.

\section{7) kavala and Gandusha [19]}

Kavala of khadira, kshiri tree prevents mainly Kaphaja disorders like Aruchi (Tastslessness), Mukhvairasya (faulty taste) Daurgandha (halitosis). Luckwarm water is best for Gandusha, luckwarm water provides laghuta (lightness) in mouth.

Sneha Gandush prevents vataja disorders of mouth like crack lips, dryness of mouth and swarabheda (loss of voice)

\section{8) Dhoomapana $[20]$}

There are 3 types of Dhoomapana-

1. Prayogika 2. Snahik 3. Vairechik

Prayogika dhoomapana has advised for daily use.It prevents head and neck region disorders caused by vata and kapha like shirogaurava,shirashoola ,kasa, shwas, hikka, karna, nasya and netra srav Tandra etc.

Smoke should be taken from nose and expelled from mouth otherwise it cause harm to eyes.

\section{9) Abhyanga [21]}

It provides strength to the body, also repairs and regenerates tissue. It pacifies vata, relieves tiredness.

Shiroabhyanga is useful for hair, provides nourishment for sense organs also improves sleep.

Padabhyanga provides strength to the feet and legs.It Relieves from stiffness, crack and dryness. It improve vision and sleep. Ushna abhyanga is useful in sheeta Ritu. And sheet abhyanga in ushna Ritu.

\section{0) Vyayama [22]}

Any kind of physical activity which which causes tiredness or sweating is Vyayam. This can include any physical activity such as walking, running any cardio workout. Specially in this lockdown situation yoga is the best exercise which provide us physical as well as mental health.

\section{1) Udwartan [23]}

Massage with Triphala churn, Yava churn That is kaphahara drugs helps for opening of skin pores, improves complexion, reduce itching, skin eruption and fat reduction also. 


\section{2) Snana [24]}

Warm water is usually used for bathing. Temperature of water changes according to seasons. It is very important part of personal hygiene. Hot water should not use for head bath, as it causes harm to hairs and eye. Bath should not be taken after meals, it causes improper digestion.

\section{3) Bhojana Vidhi -Ahara}

Ahara is considered as Mahabhaishajya (the superior medicine). Various life style disorders and numerous diseases occur due to faulty dietary habits. Which may be prevented by proper Ahara and eating habits. Acharya charak explained 8 Aharvidhi vishesh ayatan (rules) for good health.

\section{Aharvidhivisheshayatan [25]}

1) Prakriti

Considerations of Prakriti is very important to pacify Doshas and Agni, one should consume food as per his/her internal constitution.

\section{2) Karana}

Action of food also needs to be consider since specific diet offers particular health benefits.

\section{3) Samyoga}

Appropriate combinations of ingredients lead health benefits while incompatible combinations cause health problems.

4) Rashi

Ahara should be consumed in proper amount since less food causes malnutrition while excess food leads indigestion and felling of heaviness.

\section{5) Desha}

The place of meal affect process of digestion and particular meal required to take in specific demographic region.

\section{6) Kala}

Time of meal also affects nutritious value of food thus time and season should be consider befor taking meal

\section{7) Upyoga sanstha}

Food for specific purpose sometimes required to take in particular conditions.

8) Upayokta

One who follow all above rules called Upayokta. Upayokta also play vital role towards achieving health benefits of consumed food.

One should not eat without hunger. For healthy life 2 times of meal is advised. One should follow all principles of eating. Water should not be taken immediately after meal. Also, exercise, sleep, sexual activity should not be done after meal. late night food, heavy food at night should be taken. Virudhha Anna (opposite properties).

\section{4) Sleep}

Adequate amount of sleep always play important role in mental and physical health balance.

\section{DISCUSSION}

Ayurveda mainly focus on prevention of diseases. person should perform such a action which are good for his body as the officer in charge of city and charioteer in charge of the chariote protect city and the chariot respectively. Dinacharya Ideal way of daily regimen These principles are very beneficial in current era.but in this era everyone is always busy and in hurry that they can't pay full attention for maintenance of healthy lifestyle. Nobody has little time even for themselves. So, In this lockdown period we should definitely think about small changes in daily routine for healthy life. In this Pandemic situation only, physical wellness is not concern but mental health also. everyone is really depressed and negative about life. We should really work on our mental health by adapting ayurvedic principles of Ayurveda. Principle of Dinacharya and Ahara is basically related with nutrition and building of human body and also related to mental stability. balancing of Dosha is due to good Ahara which ultimately results in good health. Adaptation of some small healthy changes or habits will definitely improves health. One should definitely adapt healthy habits even in very busy schedule. One who always desires good heath should follow all principles like early bed, early rise, Exercise, Yoga, prayer meditation, pranayama, brushing, bathing, nasal oil drops, body massage, 
proper diet will improve physical as well as mental health. Thses are not big changes that one can not Adapt, these are very small changes but definitely play very big role in maintaining health.

According to AYUSH, Guduchi, Amla, Haridra, Tulsi, ashwagandha in single drug and some formulations like chyavanprash, drakshavaleha, Indukantam ghrutam, Aravindasava, Balachaturbhadra churna, Haridra glands will play great role as immunity booster in this pandemic situation.

One should regularly follow diet and regimen which keep good health and prevent diseases, which are not manifested. This article is an effort to present Ayurvedic concepts of Dinacharya and Ahara, specially fight against covid-19 pandemic by following ayurvedic rules for healthy lifestyle.

\section{SOURCES OF FUNDING}

This research received no specific grant from any funding agency in the public, commercial, or not-for-profit sectors.

\section{CONFLICT OF INTEREST}

The author have declared that no competing interests exist.

\section{ACKNOWLEDGMENT}

None.

\section{REFERENCES}

[1] Vaidya Yadavaji Trikamji, Charak Samhita, Sutrasthana, chapter30/ shlok 41,2013

[2] Vaidya yadavji trikamji, charak samhita,sutrasthana, chapter 1/ shlok 15,2013

[3] Kaviraj ambikadutt shastri, Shushrut samhita, sutrasthan, Chapter 15/ shlok 41,2013

[4] Dr.Baragale sushant sukumar, Dr shashirekha H. K. Textbook of swasthavritta, chapter 1/page no-6, 2019

[5] AYUSH Guidelines for Ayurveda practitioners for covid -19 pdf

[6] Shri satyapala bhishakacharya, kashyap samhita, page no -249,2006

[7] Dr.B.Rama rao, ashtang sangraha of vagbhata sutrasthana vol -1,page no-190/2006

[8] Vaidya, yadavji trikamj,charak samhita, page no 174/2013

[9] Vaidya yadavji trikamji, Charak samhita, sutrasthan, chapter 11/shlok 35,2013

[10] Kaviraj ambikadutt shastri, Shushrut chikitsasthan chapter 24/shlok 3,2013

[11] Brimhananda tripathi, Ashtang hridayam, sutrasthan, chapter 2/shlok 1,2006

[12] Shri bhav Mishra, Bhavprakash purv khand chapter 5/shlok 317-318,2019.

[13] Brimhananda tripathi, ashtang hridayam, sutrasthan, chapter 3/shlok 4-8,2006

[14] Brimhannda tripathi, ashtang hridayam, sutrasthan, chapter 2/shlok 2-4,2006

[15] Vaidya Yadavaji Trikamji, Charak Samhita, Sutrasthana, chapter 5/ shlok 74-75,2013.

[16] Vaidya Yadavaji Trikamji, Charak Samhita, Sutrasthana,, chapter 5/shlok 15-20,2013

[17] Brimhananda tripathi, Ashtang hridayam, sutrasthan, chapter 2/shlok 5,2006

[18] Vaidya Yadavji Trikamji, charak samhita, sutrasthan, chapter 5/shlok 56,2013

[19] Vaidya Yadavji Trikamji, charak samhita, sutrasthan, chapter 5/shlok 78,2013

[20] Vaidya Yadavji Trikamji, charak samhita, sutrasthan, chapter 5/ shlok 55,2013

[21] Vaidya Yadavji Trikamji, charak samhita, sutrasthan, chapter 5/ shlok 81,2013

[22] Vaidya Yadavji Trikamji, charak samhita, sutrasthan, chapter 7/shlok 31,2013

[23] Brimhananda tripathi, Ashtang hridayam, sutrasthan, chapter 2/ shlok 15,2006

[24] Vaidya Yadavji Trikamji, charak samhita, sutrasthan, chapter 5/ shlok 94,2013

[25] Vaidya Yadavji Trikamji, charak samhita, vimansthan, chapter 1/ shlok 21,2013 